\title{
CHARACTERIZATION OF HEADACHES IN THE PREMENSTRUAL TENSION SYNDROME
}

\author{
Yara Dadalti Fragoso', Andrea Cristina Rodrigues Guidoni ${ }^{2}$, Luciana Brites Ribeiro de Castro ${ }^{3}$
}

\begin{abstract}
Objective: Characterization of headaches in premenstrual syndrome (PMS). Although headache is one of the symptoms for PMS, no details on this headache are given by the American College of Obstetrics and Gynecology (ACOG) criteria. Method: A group of 45 fertile age women presenting PMS were invited to complete a registration diary for headache and PMS symptoms for three consecutive months. The diary included details of each headache attack, allowing for classification according to the International Headache Society criteria (IHS-2004). Results: Migraine without aura was the most common type of headache in PMS $(n=27,60 \%)$, followed by tension type headache $(n=15,30 \%)$. Only in two cases the type of headache varied among the observed months, and only in one case the diagnosis could not be concluded by the IHS-2004 criteria. Conclusion: Better clinical and therapeutic approach to headache in PMS can be achieved if the patient's type of headache could be properly characterized.
\end{abstract}

KEY WORDS: headache, migraine, tension type headache, premenstrual tension syndrome.

\section{Caracterização das cefaléias na síndrome da tensão pré-menstrual}

Resumo - Objetivo: Caracterização das cefaléias na síndrome da tensão pré-menstrual (TPM). Embora cefaléia seja um dos sintomas associados à TPM, não são fornecidos detalhes sobre esta dor pelos critérios do American College of Obstetrics and Gynecology (ACOG). Método: Um grupo de 45 mulheres em idade fértil apresentando TPM foi convidado a preencher um diário de registro de cefaléia e dos sintomas de TPM por três meses consecutivos. O diário incluía detalhes de cada crise de cefaléia, permitindo classificação de acordo com os critérios da International Headache Society (IHS-2004). Resultados: Enxaqueca sem aura foi a forma mais freqüente de cefaléia na TPM ( $n=27,60 \%)$, seguida de cefaléia tipo tensional $(n=15,30 \%)$. Em apenas dois casos a cefaléia variou entre os meses observados e em apenas um caso o diagnóstico não pôde ser conclusivo pelos critérios da IHS-2004. Conclusão: Melhor manejo clínico e terapêutico pode ser obtido na cefaléia da TPM se o tipo de cefaléia apresentado pela paciente puder ser adequadamente caracterizado.

PALAVRAS-CHAVE: cefaléia, enxaqueca, cefaléia tipo tensional, síndrome da tensão pré-menstrual.

Premenstrual syndrome (PMS) is a relatively common condition for women, who may present a variety of usually mild symptoms preceding the menstruation, affecting daily activities, but not substantially disabling ${ }^{1,2}$. Although for some women the symptoms may be debilitating, the majority of cases may consider them to be normal, not requiring medical interventions ${ }^{3}$. The symptoms may be emotional, behavioral or physical, and unspecified headache is mentioned as one of the symptoms ${ }^{4}$, affecting more than half of the women with $\mathrm{PMS}^{2}$. A dysphoric form of PMS is more disabling, often requiring medical intervention. Since the dysphoric form of PMS was not the subject of the present work, it will not be discussed fur- ther. There is no characterization of the PMS headache. Although menstrual migraine is defined, accepted and treated by medical specialists ${ }^{5}$, PMS headache might not necessary be menstrual migraine in patients with PMS. The same idea holds true for tension type headache related to the premenstrual period ${ }^{6}$.

The American College of Obstetrics and Gynecology (ACOG) defines PMS according to the presence of signs and symptoms that are present up to five days before menstruation for at least 3 menstrual cycles in a row, with complete resolution within four days after the period starts (although it is generally accepted that the symptoms should cease within a day after the period starts) ${ }^{4}$.

Medical Faculty, Universidade Metropolitana de Santos, Santos SP, Brazil: ' Head of the Department, Neurology; ${ }^{2}$ Lecturer in Gynecology; ${ }^{3}$ Graduating Medical Student.

Received 22 July 2008, received in final form 13 October 2008. Accepted 21 November 2008.

Dra. Yara Dadalti Fragoso - Department of Neurology / Medical Faculty UNIMES - Rua da Constituição 374 - $11015-470$ Santos SP - Brasil. E-mail: yara@bsnet.com.br 
Self-assessment of PMS is reliable, and should be performed for at least three consecutive menstrual cycles ${ }^{7}$.

The objective of the present work was to investigate the characteristics of headaches that are typical of PMS, not present at other periods of the month, in women with PMS who were not undergoing consultations or seeking treatment for PMS or headache.

\section{METHOD}

The present work was approved by the Ethical Research Committee of Universidade Metropolitana de Santos. All participants were volunteers who were aware of the investigative character of this research and consented to take part in it.

All women participating in this study were fertile, having at least one year of PMS symptoms, including headaches that occurred exclusively in this period of their menstrual cycle. The inclusion of women presenting headache only during PMS allowed for exclusion of "menstrual magnification", since migraines, seizure disorder, irritable bowel syndrome, asthma, chronic fatigue syndrome, and allergies are among the many conditions whose symptoms are subject to menstrual magnification ${ }^{8}$. None presented other medical conditions that could interfere in this study; they all claimed to be in good health. Their self-assessment of PMS included at least five signs and symptoms from the ACOG recommended diagnostic criteria ${ }^{4}$. Women participating in this study were not undergoing treatment for PMS or head- ache, and their personal management of this monthly headache was also assessed. All participants completed a three-month registration of their headache characteristics in order to allow for characterization according to the strict International Headache Society criteria (IHS-2004) ${ }^{9}$. None of the women entering this study presented dysphoric PMS.

Data analysis consisted of descriptive findings in this group of women.

\section{RESULTS}

All women entering this prospective study $(n=45)$ completed the three month detailed registration of PMS symptoms and headache characterization. PMS symptoms and signs were present between seven days before menstruation, up to the day it started. Results are summarized in the Table.

Out aura was the most frequent presentation of headache in the premenstrual period, associated with PMS signs and symptoms. Twenty seven women (60\%) reported attacks of migraine without aura every month, starting two to four days before menstruation and invariably ceasing on the first day of it. Headache fulfilling the HIS2004 diagnostic criteria for tension type headache (TTH) was reported every month by 15 women (30\%), two to five days before menstruation. Only two women presented alternating attacks of TTH and migraine without aura dur-

Table. Signs and symptoms reported (present for at least two months) by 45 women registering them for three consecutive months. Reports from three patients were excluded from the separate analysis (one probable TTH and two cases of alternating TTH and migraine without aura).

\begin{tabular}{|c|c|c|c|}
\hline Signs and symptoms & $\begin{array}{l}\text { Total group } \\
\qquad(n=45)\end{array}$ & $\begin{array}{l}\text { Migraine without } \\
\text { aura }(n=27)\end{array}$ & $\begin{array}{c}\text { Tension type } \\
\text { headache }(n=15)\end{array}$ \\
\hline \multicolumn{4}{|l|}{ ACGO criteria } \\
\hline Depression & 14 & 10 & 3 \\
\hline Angry outbursts & 7 & 6 & 1 \\
\hline Being irritable & 26 & 20 & 3 \\
\hline Crying spells & 10 & 3 & 5 \\
\hline Anxiety & 10 & 8 & 1 \\
\hline Confusion & 4 & 3 & 1 \\
\hline Social withdrawn & 2 & 1 & 1 \\
\hline Poor concentration & 9 & 7 & 1 \\
\hline Sleep disturbance & 10 & 8 & 1 \\
\hline Thirst and appetite changes & 29 & 24 & 4 \\
\hline Tender breasts & 3 & 3 & - \\
\hline Bloating and weight gain & 7 & 5 & 1 \\
\hline Headache & 45 & 27 & 15 \\
\hline Swelling of extremities & 9 & 9 & - \\
\hline Aches and pains & 3 & 1 & 1 \\
\hline \multicolumn{4}{|l|}{ Not ACGO criteria } \\
\hline Nausea & 31 & 23 & 6 \\
\hline Fatigue & 10 & 3 & 7 \\
\hline Dizziness & 6 & 5 & 1 \\
\hline Decreased libido & 8 & 8 & - \\
\hline
\end{tabular}


ing the assessed period of observation. In one other case, the headache had to be classified as "probable TTH", since occasional stabbing of pain could be triggered by physical activity. Two women with TTH failed to present headache in one of the months of observation.

In $35 \%$ of women, the headache during PMS showed no variation in duration, localization, type of pain or associated migraine and PMS symptoms along the observed three month period.

Apart from signs and symptoms belonging to the ACGO criteria for PMS, several women spontaneously reported other symptoms, such as nausea $(n=31)$, fatigue $(n=10)$, decreased libido $(n=8)$ and dizziness $(n=6)$ during PMS.

Women with migraine without aura associated to PMS presented more severe and incapacitating headache attacks, lasting longer and with less response to analgesics, anti-inflammatory drugs and ergot derivates. They also presented more disabling associated PMS symptoms, such as depression, irritability, anxiety, anger outbursts, and food intolerance. Women with TTH presented less intense headache with good response to single doses of analgesics. Their PMS symptoms were more frequently crying spells and fatigue.

\section{DISCUSSION}

Headache is considered to be one of the diagnostic criteria for PMS. Only a few research papers consider the possibility of an association between PMS and migraine ${ }^{10-12}$. However, the type of headache in PMS has not been properly characterized, allowing space for mismanagement of these headache attacks. Once the details of this particular headache are identified, it is possible to give it a particular therapeutic approach, tailored for the needs of each patient. The knowledge of systematic presentation of the very same headache for each PMS period for the vast majority of patients may lead to better treatment. Indeed, when identifying that this headache is migraine without aura related to the menstrual period, the same approach given to menstrual migraine without PMS may suffice ${ }^{5}$. The same can be said for menstrual $\mathrm{TTH}^{6}$.

It was not the objective of the present study to correlate the intensity of PMS symptoms to that of the head- ache pain. The long list of possible PMS symptoms allows only for a description of findings associated with migraine or TTH. Hence, the study design did not envisage statistical analysis on these findings.

It is interesting to observe that PMS symptoms seem to be the same month after month, and the headache characteristics were equally similar along the observed period of time in the present work.

In summary, premenstrual headache often fulfills all the HIS-2004 criteria for migraine or TTH. On the other hand, in a very small number of cases, it fulfills the diagnostic criteria for both conditions or cannot be classified. This finding may be relevant for specific management of individual PMS patients.

ACKNOWLEDGEMENT - The authors are grateful to Dr Jose Geraldo Speciali for support in performing this work.

\section{REFERENCES}

1. Yonkers KA, O'Brien PM, Eriksson E. Premenstrual syndrome. Lancet 2008;371:1200-1210.

2. Silva CM, Gigante DP, Carret ML, Fassa AG. Population study of premenstrual syndrome. Rev Saude Publica 2006;40:47-56.

3. Reilly J, Kremer J. A qualitative investigation of women's perceptions of premenstrual syndrome: implications for general practitioners. Br J Gen Pract 1999;49:783-786.

4. American College of Obstetricians and Gynecologists. Premenstrual Syndrome: Clinical Management Guidelines for Obstetrician-Gynecologists. ACOG Practice Bull 2000;15:1-9.

5. MacGregor EA. Menstrual Migraine. Curr Opin Neurol 2008;21: 309-315.

6. Arjona A, Rubi-Callejon J, Guardado-Santervas P, Serrano-Castro P, Olivares J. Menstrual tension-type headache: evidence for its existence. Headache 2007;47:100-103.

7. Bertone-Johnson ER, Hankinson SE, Johnson SR, Manson JE. A simple method of assessing premenstrual syndrome in large prospective studies. J Reprod Med 2007;52:779-786.

8. Frackiewicz EJ, Shiovitz TM. Evaluation and management of premenstrual syndrome and premenstrual dysphoric disorder. J Am Pharm Assoc 2001:41:437-447.

9. The International Classification Of Headache Disorders. $2^{\text {nd }}$ edition. Cephalalgia 2004;24(Suppl 1):S9-S160.

10. Facchinetti F, Neri I, Martignone E, Fioroni L, Nappi G, Genazzani AR. The association of menstrual migraine with the premenstrual syndrome. Cephalalgia 1993;13:422-425.

11. Martin VT, Wernke S, Mandell K, et al. Symptoms of premenstrual syndrome and their association with migraine headache. Headache 2006;46:125-137.

12. Goldberg J, Wolf A, Silberstein S, et al. Evaluation of an electronic diary as a diagnostic tool to study headache and premenstrual symptoms in migraneurs. Headache 2007;47:384-396. 